\title{
Simulation of Fall Armyworm (Spodoptera frugiperda) Attacks and the Compensative Response of Quality Protein Maize (Zea mays, var. Mudishi-1 and Mudishi-3) in Southwestern DR Congo
}

\author{
Jean Pierre Kabongo Tshiabukole1,2*, Gertrude Pongi Khonde1,2, André Matondo Phongo1, \\ Nlandu Ngoma1, Amand Mbuya Kankolongo1,2, Roger Kizungu Vumilia ${ }^{3}$, \\ Antoine Mumba Djamba ${ }^{2}$
}

${ }^{1}$ National Maize Program, National Institute for Agronomic Study and Research, Gandajika, DRC

${ }^{2}$ Faculties of Agricultural Sciences of the National Pedagogical University, Gandajika, DRC

${ }^{3}$ INERA DG, University of Kinshasa, Gandajika, DRC

Email: *jpkabon2005@gmail.com

How to cite this paper: Tshiabukole, J.P.K., Khonde, G.P., Phongo, A.M., Ngoma, N., Kankolongo, A.M., Vumilia, R.K. and Djamba, A.M. (2021) Simulation of Fall Armyworm (Spodoptera frugiperda) Attacks and the Compensative Response of Quality Protein Maize (Zea mays, var. Mudishi-1 and Mudishi-3) in Southwestern DR Congo. Open Access Library Journal, 8: e7217.

https://doi.org/10.4236/oalib.1107217

Received: February 4, 2021

Accepted: March 28, 2021

Published: March 31, 2021

Copyright $\odot 2021$ by author(s) and Open Access Library Inc.

This work is licensed under the Creative Commons Attribution International License (CC BY 4.0).

http://creativecommons.org/licenses/by/4.0/

\section{(c) (i) Open Access}

\begin{abstract}
In this paper, to assess the varietal ability to compensate defoliation damage caused by the fall armyworm, a trial was carried out at the INERA Mvuazi research center. The aim of this study was to determine the limit threshold of damage that could cause the significant loss of the harvest of the quality protein maize distributed in the Democratic Republic of the Congo. To do this, three factors including two varieties (Mudishi-1 and Mudishi-3) of quality protein maize, four rating damage and two growth stages were used into a factorial design with 3 replications. Simulation of damage caused by FAW consisted of cutting of blades for all visible leaves of plants. Damage rates simulating leaf destroying were $0 \%, 25 \%, 50 \%, 75 \%$ and $100 \%$, occurring at two growth stages: stage V3 (2 to 4 weeks after emergence) and stage V7 (flowering stage). Results showed that damage factor combined with growth stage factor significantly influenced $(p<0.05)$ the yield component variables including yield losses, harvest rate, ear sizes, number of ears harvested and yield as well as the market quality of the ears, based on appearance quotation. Damage rate more than $50 \%$, at all growth stages studied, caused grain losses upper than $50 \%$ regardless of variety. However, damage less than $50 \%$ at V3 stage resulted in grain losses under $10 \%$. At the end of this study, we showed that the varieties of maize QPM (Mudishi-1 and Mudishi-3) would be able to compensate the damage caused by the FAW and achieve its yield, if the attacks damaging $25 \%$ of the leaves occur during V3.
\end{abstract}




\section{Subject Areas}

Agricultural Science

\section{Keywords}

QPM, Yield Losses, Growth Stage, FAW, Rate Damage

\section{Introduction}

Fall armyworm (FAW) Spodoptera frugiperda, is a lepidopteran pest native to the tropical and subtropical regions of the Americas [1] [2].

FAW larval stage can completely defoliate seedling and early-vegetative stage of maize plants, stunt plant growth, or kill seedlings [3] [4] giving them a shredded appearance [5] when it is not properly managed. FAW prefers maize, but can feed on more than 80 additional plant species, including rice, sorghum, millet, sugarcane, vegetables such as cabbage, salad, eggplant, pepper and cotton [5] [6]. The pest feeds inside whorls and can destroy silks, panicles and developing grains reducing yields through direct losses, exposure of ears to infections and loss of quality and quantity of grain [5]. But the foliar damage caused by FAW in many cases does not result in dramatic yield reduction [7]. A quantification of the potential yield losses is still speculative, as many variables come into play between FAW infestation and yield reduction [6].

Different levels of damages have been reported from different countries [8] [9] [10]. But rarely, those damages levels are related to the yield losses except some scanty studies [7] [11] [12]. Yield loss could be lower due to climatic factors, the constitution of natural enemies or improved management [13].

Fall armyworm (FAW) Spodoptera frugiperda (J.E. Smith) invaded Africa in 2016 [14] [15]. Native to tropical and subtropical regions of the Americas [16], FAW presence is now confirmed in 45 African countries [13]. It is causing significant damage to maize crops, threatening therefore, the livelihood of farmers who rely on maize production [17].

[18] estimated the impact of FAW between $22 \%$ and $67 \%$ of the yield respectively in Ghana and Zambia, resulting in losses in millions of US dollars. Similarly, [19] estimated the impact of FAW at 32\% of yields in Ethiopia and $47 \%$ in Kenya. These estimations, however, are based on socio-economic surveys focused on farmers' perceptions, but not on rigorous field scouting methods [11]. Average loss of maize reported by farmers in Ghana was $26.6 \%$ and $35 \%$ in Zambia. This is much less than what was reported in 2017.

According to an unpublished survey report from the Ministry of Agriculture, Fisheries and Livestock (MINAGRI), 800,000 ha of maize fields had been devastated by this pest in 87 of 150 territories in 2017. Based on a rough estimate of around 500 hectares affected by territory, the DRC could see up to 25,000 hectares of maize affected, representing more than US $\$ 20$ million in losses for local 
populations [6]. Following the financial statistics, these losses represent a significant risk in terms of food and nutritional insecurity because they also represent 250 million meals [6].

The response of maize yield to damage caused by FAW has been studied in the field several times on the American continent. A review of the study on the response of maize yield to damage caused by FAW has shown that, although cause for concern, the damage of FAW in maize is not devastating. Despite FAW attacks, damaged maize plants are able to compensate for leaf damage, especially if nutrition and moisture soil conditions are good [20]. Although some studies have shown yield reductions of more than $50 \%$ due to FAW, the majority of trials have shown yield reductions of less than $20 \%$, even with a high FAW infestation, up to $100 \%$ of infested plants [21].

The aim of the present study is to assess the ability to compensate for leaf damage caused by FAW at two growth stages of quality protein maize under growing conditions in south-west DRC.

\section{Materials and Method}

\subsection{Experimental Site, Analyzes and Characteristics of Soils}

Trial was conducted during the 2018-2019 growing season, from October 25, 2018 to March 14, 2019 at Mvuazi research center of the National Institute for Agronomic Study. Mvuazi is located at $14^{\circ} 54^{\prime}$ East longitude and $5^{\circ} 21^{\prime}$ South latitude, at $470 \mathrm{~m}$ of altitude (Figure 1).

The soil of Mvuazi belongs to the Sudano-Guinean climatic zone of AW4 type [23]. This soil is characterized by a low organic matter content and a low water retention capacity, resulting to a low availability of nitrogen [24] and the orthic soil type [25] (Table 1). The climatic data recorded during the experimental period are presented in Table 2 .

\subsection{Plant Material}

Varieties Mudishi-1 (M1) and Mudishi-3 (M3) selected by the National Maize

Table 1. Selected chemical and physical parameters for soils of experimental site.

\begin{tabular}{|c|c|c|c|c|c|c|c|c|c|}
\hline $\begin{array}{l}\text { Parameters } \\
(u[10] N i t)\end{array}$ & Soil pH & $P 1(p p m)$ & $K(p p m)$ & $\mathrm{Ca}(\mathrm{ppm})$ & $M g(p p m)$ & $M n(p p m)$ & $S(p p m)$ & $C u(p p m)$ & $B(p p m)$ \\
\hline Results & 5.76 & 14 & 105 & 1505 & 229 & 55 & 23 & 12.30 & 0.21 \\
\hline Guide Low & 6.00 & 30 & 268 & 1651 & 165 & 100 & 20 & 2.00 & 1.00 \\
\hline Guide high & 7.00 & 100 & 537 & 2064 & 264 & 250 & 200 & 10.00 & 2.00 \\
\hline $\begin{array}{l}\text { Parameters } \\
(u[10] N i t)\end{array}$ & $Z n(p p m)$ & $\mathrm{Na}(p p m)$ & $F e(p p m)$ & $C E C(\mathrm{meq} / 100 \mathrm{~g})$ & $O C(m e q / 100 \mathrm{~g})$ & Silt (\%) & Sand (\%) & Clay (\%) & $N(\%)$ \\
\hline Results & 7.98 & 47 & 194 & 13.76 & 4.07 & 13 & 49 & 39 & 0.21 \\
\hline Guide Low & 4.00 & 0 & 150 & 15.00 & & 30 & 30 & 20 & 0.20 \\
\hline Guide high & 20.00 & 158 & 350 & 30.00 & & 50 & 55 & 55 & 0.50 \\
\hline
\end{tabular}


Table 2. Climatic data recorded during the experimental period.

\begin{tabular}{ccccccc}
\hline Year & $\mathbf{2 0 1 8}$ & $\mathbf{2 0 1 8}$ & $\mathbf{2 0 1 8}$ & $\mathbf{2 0 1 9}$ & $\mathbf{2 0 1 9}$ & $\mathbf{2 0 1 9}$ \\
\hline Month & October & November & December & January & February & March \\
\hline TMax $\left({ }^{\circ} \mathrm{C}\right)$ & 30.76 & 30.95 & 29.63 & 21.68 & 30.95 & 31.98 \\
TMin $\left({ }^{\circ} \mathrm{C}\right)$ & 20.3 & 21.55 & 21.46 & 28.10 & 21.33 & 21.23 \\
Rain $(\mathrm{mm})$ & 179.1 & 252.90 & 197.70 & 100.90 & 435.30 & 60.50 \\
Nber. of rain $[18]$ Days & 9 & 10.00 & 7.00 & 6.00 & 16.00 & 3.00 \\
Rel. hum $(\%)$ & 74.85 & 79.96 & 82.41 & 80.32 & 81.99 & 74.24 \\
T.mean $\left({ }^{\circ} \mathrm{C}\right)$ & 25.52 & 26.23 & 32.56 & 26.05 & 26.11 & 26.36 \\
\hline
\end{tabular}

Tmax $=$ Temperature maximal, $\mathrm{Tmin}=$ Temperature $\mathrm{mi}[10]$ Nimal, Rain $=$ Rainfall, Rel.Hum $=$ Relative humidity, T.mean = Temperature mean.

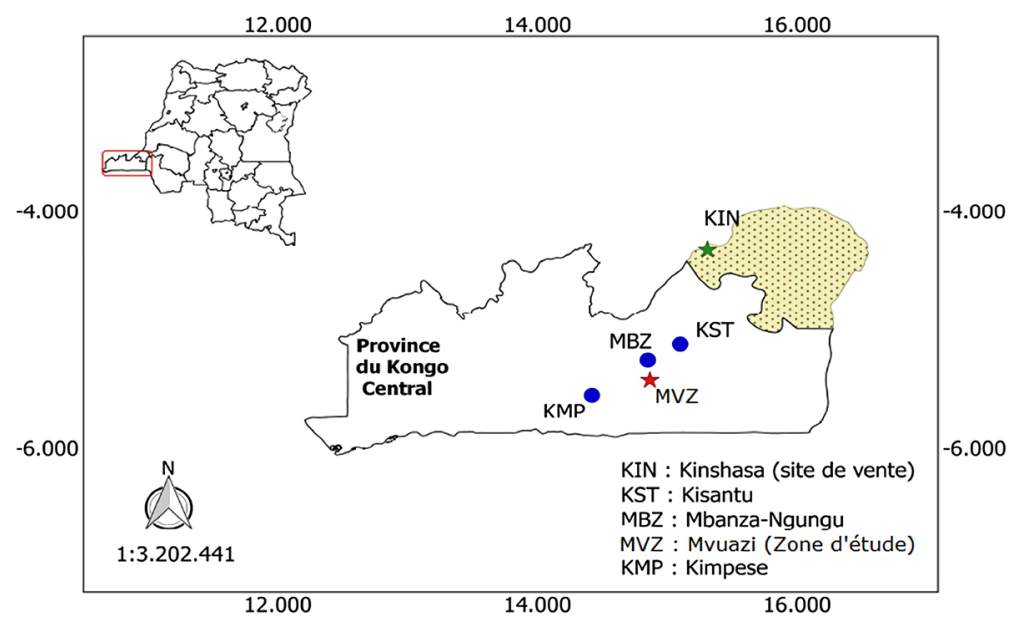

Figure 1. Geographic location of the INERA Mvuazi Research Center (source: [22]).

Program of INERA, are cultivated in the most of agro-ecological zones of the DRC. They are preferred for their resistance to leaf diseases, to root and stem lodging, their yield potential of 4 to $6 \mathrm{t} / \mathrm{ha}$ [26] and their high rate in lysine and tryptophan [27].

\subsection{Experimental Design and Treatments}

The factorial experimental design with 3 replications and 3 factors was used (Figure 2). The first factor (percentage of damage by cutting the blade of leaves) consisted of five levels, namely $0 \%$ (no damage, which corresponds to the controls), $25 \%$ (leaves having lost the $25 \%$ of the blade), $50 \%$ (leaves having lost the half of the blade), $75 \%$ (leaves having lost $75 \%$ of the blade) and $100 \%$ (leaves having lost all of the blade). The second factor (growth stage) consisted of two levels: V3 and VT as defined by McWilliams et al. (1999), V3 which corresponds to defoliation at the $2-4$ week after emergence and VT which corresponds to defoliation at the stage of flowering. The third factor (variety) was made up of two levels: M1 and M3. The maize plants have been sown at $0.75 \mathrm{~m} \times 0.50 \mathrm{~m}$ spacing with 2 seeds per hill in the $1.50 \mathrm{~m} \times 2 \mathrm{~m}$ plots. 


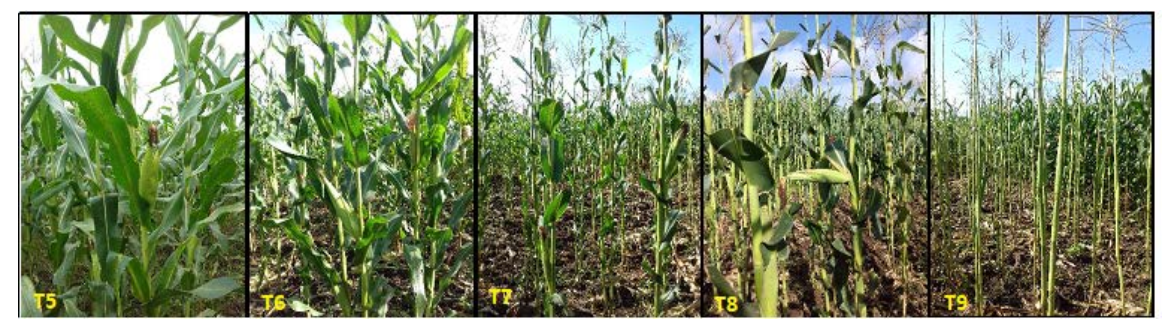

Figure 2. Simulation of defoliation by cutting the blade at $0 \%, 25 \%, 50 \%, 75 \%$ and $100 \%$ at stage VT.

The combination of percentage of damage (factor in sub-sub-plot), stages of growth (factor in sub-plot) and variety (factor in plot) allowed a total of twenty (20) treatments:

T0.1 (M1:0\%:V3), T0.2 (M3:0\%:V3), T1.1 (M1:25\%:V3), T1.2 (M3:25\%:V3), T2.1 (M1:50\%:V3), T2.2 (M3:50\%:V3), T3.1 (M1:75\%:V3), T3.2 (M3:75\%:V3), T4.1 (M1:100\%:V3), T4.2 (M3:100\%:V3), T5.1 (M1:0\%:VT), T5.2 (M3:0\%:VT), T6.1 (M1:25\%:VT), T6.2 (M3:25\%:VT), T7.1 (M1:50\%:VT), T7.2 (M3:50\%:VT), T8.1 (M1:75\%:VT), T8.2 (M3:75\%:VT, T9.1 (M1:100\%:VT), T9.2 (M3:100\%:VT).

\subsection{Data Collection}

Data collected concerned observations made on some parameters relating to yield performance were:

- Number of plants per useful plot (without borders)

- Number of ears harvested per useful plot

- Percentage of harvest: Number of ears of corn harvested from number of plants per plot multiplied by one hundred

- Percentage of marketable ears based on quotation of appearance: number of healthy ears (not attacked) on number of ears harvested multiplied by one hundred, the quotation scale of appearance of ear is from 1 to 5 where $1=$ excellent, 2 =good, 3 = fairly good, $4=$ not good and $5=$ poor) [26]

- Ear diameter (mm)

- Ear length (cm)

- Yield: was measured in kilogram $/ \mathrm{m}^{2}$ following the formula here beyond.

$$
\text { Yield }=(F W *(100-F G M / 100-D G M) *(G W / E W) *(1 / U A))
$$

where:

FW: Field Weigh

FGM: Field Grain Moisture

DGM: Dry Grain Moisture

GW: Grain Weigh

EW: Ear Weigh

UA: Useful Area

- Grain loss (\%): weight of the grains of a treatment with damage on weight of grains of the control without damage multiplied by a hundred.

\section{Statistical analyzes:}


The collected data were analyzed using packages agricolae and FactomineR of R3.1.3 software to determine difference among treatments by analysis of variance following the linear model (aov(y Trait ${ }^{\star}$ Trait $2^{\star}$ Trait1+error (replication/Trait princ)) with respect to various growing and yield parameters. The means of treatment that exhibited significant differences were separated using the least significant difference (LSD) post-hoc test. A principal component analysis (PCA) to detect the correlations between the variables studied.

\section{Results and Discussion}

\subsection{Analysis of Variance of Study Parameters}

Table 3 shows the effects of factors and their interaction on characteristics parameters observed during plant growth and yield parameters.

With regard to Table 3, it can be seen that the damage caused by defoliation, the growth stage and their combined effect influenced significantly $(\mathrm{p}<0.05)$ the number of ears harvested, the ear sizes (diameter and length), the harvest rate, the percentage of marketable ears, the yield and the yield losses. No significant difference ( $p>0.05$ ) was observed between treatments for the number of plants per plot. However, the variety factor and most of its effects interacting with the other factors did not directly influence $(p>0.1)$ the yield as well as the components of the yield (loss, harvest rate, marketable ears, size of ears).

\subsection{Principal Component Analysis (PCA)}

PCA was performed on 8 active variables characterizing the treatments based on the data of the combination of factors. More than $87 \%$ of variability are represented on the plane formed by two exes Dim1 and Dim2 (Figure 3(A)). Dim1 is characterized by strong correlations between variables. This dimension benefits from the strong contributions of variables linked to productivity, including loss, yield, harvest rate, ear size, number of ears harvested. Losses are greatest when yields are low, however the other variables correlate positively with each other variables. Dim2 is characterized only by the number of plants

Table 3. Analysis of variance.

\begin{tabular}{|c|c|c|c|c|c|c|c|c|}
\hline Factors & Nber of Plant & $\begin{array}{l}\text { Nber of Ear } \\
\text { Harvested }\end{array}$ & $\begin{array}{l}\text { Ear Diameter } \\
\quad(\mathrm{mm})\end{array}$ & $\begin{array}{l}\text { Ear Lenght } \\
\quad(\mathrm{cm})\end{array}$ & Ear Market \% & Harvest \% & Yield $\left(\mathrm{kg} / \mathrm{m}^{2}\right)$ & Loss $\%$ \\
\hline Var & 0.108 & $0.004835^{\star *}$ & 0.41 & 0.772865 & 0.85085 & $0.0160^{*}$ & 0.157555 & 0.1931 \\
\hline$D m g$ & 0.112 & $1.14 \mathrm{e}-07^{\star * \star}$ & $1.21 \mathrm{e}-08^{* * *}$ & $7.18 \mathrm{e}-07^{\star * *}$ & $0.00125^{\star *}$ & $1.54 \mathrm{e}-15^{\star * \star}$ & $0.000187^{\star * \star}$ & $1.12 \mathrm{e}-07^{* * *}$ \\
\hline Gstp & 0.831 & $0.000534^{\star * \star}$ & $0.000154^{\star * \star}$ & $0.000282^{\star * \star}$ & $0.00884^{\star *}$ & $5.89 \mathrm{e}-10^{* * *}$ & $0.000953^{\star * *}$ & $0.0124^{*}$ \\
\hline $\operatorname{Var}^{*} \mathrm{Dmg}$ & 0.500 & 0.593354 & 0.512405 & 0.513076 & 0.31872 & 0.6571 & $0.631025^{\star *}$ & 0.6244 \\
\hline $\operatorname{Var}^{\star} G s t p$ & 0.943 & 0.277669 & 0.615947 & 0.285471 & 0.84882 & 0.0969. & 0.978240 & 0.1523 \\
\hline$D m g{ }^{\star} G s t p$ & 0.631 & $5.53 e-06^{* * *}$ & $8.67 \mathrm{e}-08^{* * *}$ & $3.03 e-07^{\star * *}$ & $0.00846^{\star *}$ & $1.35 \mathrm{e}-13^{* * *}$ & $0.000456^{* * *}$ & $0.0441^{*}$ \\
\hline $\operatorname{Var}{ }^{*} D m g{ }^{\star} G s t p$ & 0.732 & 0.545530 & 0.279982 & 0.701105 & 0.48768 & 0.6835 & 0.807966 & 0.4680 \\
\hline
\end{tabular}

Sig[10]Nif. codes: 0 “***” 0.001 “**” 0.01 “*” 0.05 “.” 0.1 “” 1, Var = Variety; Dmg = Damage; Gstp = Growht stape; V3: 3 to 4 weeks after sowing; VT: Flowering stage. 
(A)

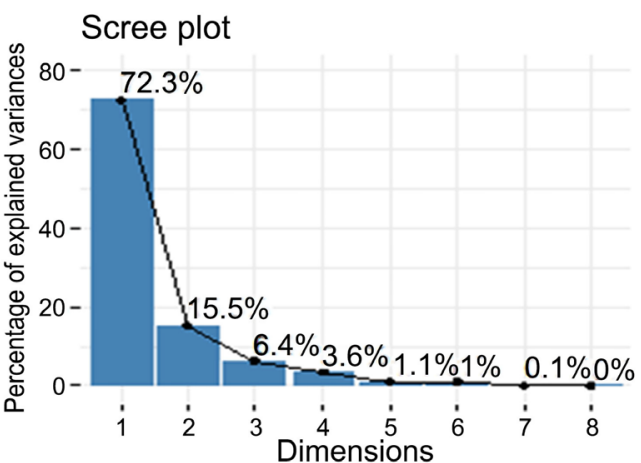

Individuals factor map (PCA)

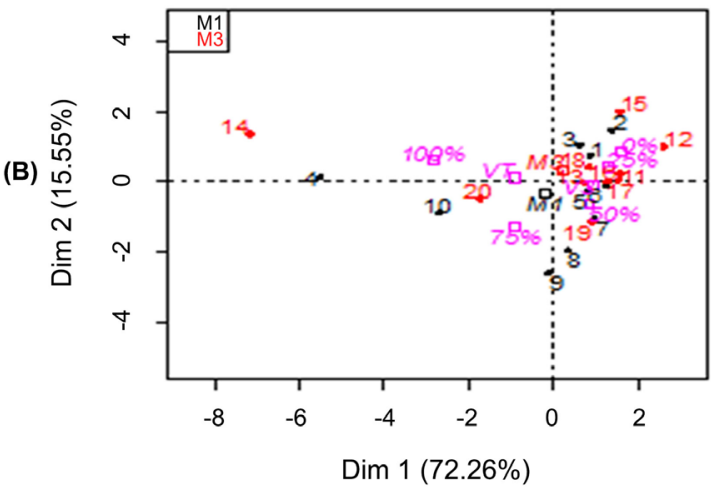

Variables factor map (PCA)

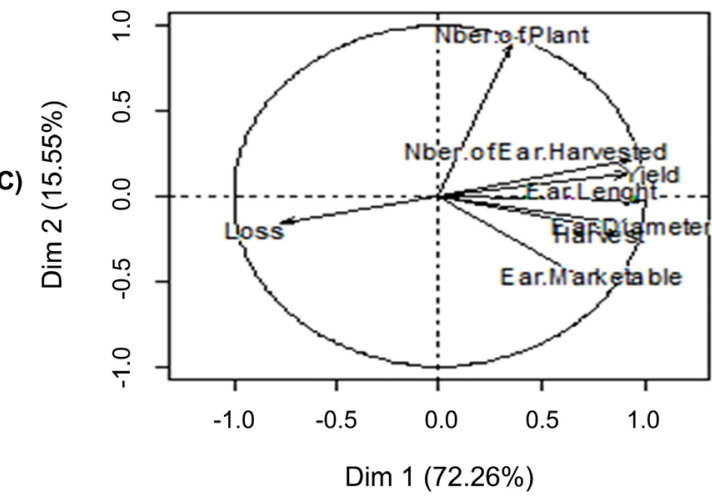

Figure 3. A. Scree plot, B. Individuals factor map and C. variable factor map according to PCA.

per plot (Figure $3(C)$ ). Less dispersion of varieties was observed around two axes (Figure 3(B)). However, there was a large dispersion of the damage rate factor compared to two axes. Based on the contributions of the factors on Dim1 (Figure 3(B)), it seems that the two varieties M1 and M3 combine similar values of the variables studied. However, there is a wide dispersion in damage rates.

\subsection{Number of Plants per Plot}

For all factors taken individually and in interaction of factors, the number of plants per plot varied from 5.33 to 9.66 plants respectively for T3.1 and T1.2 (Table 4). The results of analysis of variance showed non-significant effects ( $p>$ 0.05 ) of factors and interactions between factors on the number of plant per plot. However, there were noticeable variations between the factors resulting in a large coefficient of variation. These variations should be linked to variety effects ( $\mathrm{p}=0.1$ ) by looking at Table 3 .

\subsection{Number of Ears Harvested}

Regardless of variety, the number of ears harvested per plot varied significantly between the factors and interactions studied. The highest number, 9.66 ears per $\mathrm{m}^{2}$, was recorded at $\mathrm{T} 1.1$ and the lowest number, 0 ears per $\mathrm{m}^{2}$, was recorded at T9.2. In general, the low numbers of ears harvested were recorded for two varieties subjected to $100 \%$ of defoliation at flowering stage (VT). High numbers of 
Table 4. Comparative study of growing, yield and yield losing variables.

\begin{tabular}{|c|c|c|c|c|c|c|c|c|}
\hline Treatment & $\begin{array}{c}\text { Nber of } \\
\text { Plant/ plot }\end{array}$ & $\begin{array}{c}\text { Nber of Ear } \\
\text { Harvl plot }\end{array}$ & $\begin{array}{c}\text { Ear Diameter } \\
\quad(\mathrm{mm})\end{array}$ & $\begin{array}{l}\text { Ear Lenght } \\
\quad(\mathrm{cm})\end{array}$ & $\begin{array}{c}\text { Ear Marketable } \\
(\%)\end{array}$ & Harvest (\%) & Yield $\left(\mathrm{kg} / \mathrm{m}^{2}\right)$ & Loss (\%) \\
\hline$T 0.1$ & 7.66abcd & 7.00abcdef & $46.82 \mathrm{a}$ & $15.79 \mathrm{a}$ & $40.52 \mathrm{cde}$ & $92.50 \mathrm{bcd}$ & $0.24 \mathrm{ab}$ & $0.00 \mathrm{~g}$ \\
\hline 70.2 & 7.33abcd & $8.33 \mathrm{abc}$ & $44.66 \mathrm{a}$ & $15.53 \mathrm{a}$ & 55.92abcde & $114.28 \mathrm{a}$ & $0.27 \mathrm{ab}$ & $0.00 \mathrm{~g}$ \\
\hline$T 1.1$ & 7.33abcd & $6.33 \mathrm{bcdef}$ & $48.07 \mathrm{a}$ & $14.29 \mathrm{ab}$ & $72.22 \mathrm{abcd}$ & $86.90 \mathrm{bcde}$ & $0.22 \mathrm{ab}$ & $8.44 \mathrm{fg}$ \\
\hline$T 1.2$ & $9.66 \mathrm{a}$ & $9.66 a$ & $44.47 \mathrm{a}$ & $15.37 \mathrm{a}$ & $61.85 \mathrm{abcde}$ & $100.00 \mathrm{abc}$ & $0.28 \mathrm{ab}$ & 43.31cdef \\
\hline$T 2.1$ & $6.66 \mathrm{bcd}$ & $6.66 \mathrm{bcdef}$ & $46.06 \mathrm{a}$ & $13.45 \mathrm{abc}$ & $84.12 \mathrm{ab}$ & $100.00 \mathrm{abc}$ & $0.22 \mathrm{ab}$ & $8.00 \mathrm{fg}$ \\
\hline$T 2.2$ & $8.00 \mathrm{abcd}$ & $8.00 \mathrm{abcd}$ & $46.52 \mathrm{a}$ & $14.65 \mathrm{ab}$ & $84.12 \mathrm{ab}$ & $100.00 \mathrm{abc}$ & $0.27 \mathrm{ab}$ & $49.83 \mathrm{cdef}$ \\
\hline$T 3.1$ & $5.33 \mathrm{~d}$ & $4.66 \mathrm{ef}$ & $46.50 \mathrm{a}$ & $13.39 \mathrm{abc}$ & $90.47 \mathrm{a}$ & $92.59 \mathrm{bcd}$ & $0.20 \mathrm{bc}$ & $55.33 \mathrm{bcde}$ \\
\hline$T 3.2$ & 7.00abcd & 7.00abcdef & $47.16 \mathrm{a}$ & $15.81 \mathrm{a}$ & $90.47 \mathrm{a}$ & $100.00 \mathrm{abc}$ & $0.27 \mathrm{ab}$ & 75.88abcd \\
\hline$T 4.1$ & $8.33 \mathrm{abc}$ & 7.00abcdef & $43.69 \mathrm{a}$ & $15.12 \mathrm{a}$ & $50.99 \mathrm{bcde}$ & $85.00 \mathrm{cde}$ & $0.28 \mathrm{ab}$ & 38.30cdefg \\
\hline$T 4.2$ & 7.33abcd & 7.33abcde & $45.33 \mathrm{a}$ & $15.70 \mathrm{a}$ & 57.61 abcde & $100.00 \mathrm{abc}$ & $0.22 \mathrm{ab}$ & $34.17 \mathrm{defg}$ \\
\hline$T 5.1$ & $8.66 \mathrm{ab}$ & $8.33 \mathrm{abc}$ & $48.69 \mathrm{a}$ & $16.49 \mathrm{a}$ & $45.50 \mathrm{bcde}$ & $95.83 \mathrm{bcd}$ & $0.22 \mathrm{ab}$ & $0.00 \mathrm{~g}$ \\
\hline$T 5.2$ & $8.66 \mathrm{ab}$ & $9.00 \mathrm{ab}$ & $48.61 \mathrm{a}$ & $17.29 \mathrm{a}$ & $76.38 \mathrm{abc}$ & $100.33 \mathrm{ab}$ & $0.35 \mathrm{a}$ & $0.00 \mathrm{~g}$ \\
\hline$T 6.1$ & 7.66abcd & 7.33abcde & $48.41 \mathrm{a}$ & $16.35 \mathrm{a}$ & 73.33abc & $95.23 \mathrm{bcd}$ & $0.29 \mathrm{ab}$ & $50.53 \mathrm{cdef}$ \\
\hline$T 6.2$ & 7.66abcd & 7.33abcde & $48.63 \mathrm{a}$ & $16.39 \mathrm{a}$ & $73.14 \mathrm{abc}$ & $94.44 \mathrm{bcd}$ & $0.30 \mathrm{ab}$ & $21.70 \mathrm{efg}$ \\
\hline$T 7.1$ & $5.66 \mathrm{~cd}$ & $5.66 \mathrm{cdef}$ & $46.15 a$ & $14.59 \mathrm{ab}$ & 77.77abc & $100.00 \mathrm{abc}$ & $0.18 \mathrm{bcd}$ & $25.26 \mathrm{efg}$ \\
\hline$T 7.2$ & $8.00 \mathrm{abcd}$ & $8.33 \mathrm{abc}$ & $46.46 \mathrm{a}$ & $14.48 \mathrm{ab}$ & 60.33abcde & $100.33 \mathrm{ab}$ & $0.20 \mathrm{bc}$ & $41.62 \mathrm{cdefg}$ \\
\hline$T 8.1$ & $6.00 \mathrm{bcd}$ & $4.33 \mathrm{f}$ & $37.06 \mathrm{a}$ & $8.95 \mathrm{~cd}$ & $30.00 \mathrm{ef}$ & $74.60 \mathrm{e}$ & $0.05 \mathrm{de}$ & $76.91 \mathrm{~g}$ \\
\hline$T 8.2$ & 7.00abcd & $5.33 \mathrm{def}$ & $41.21 \mathrm{a}$ & $10.33 b c$ & $50.00 \mathrm{bcde}$ & $79.36 \mathrm{de}$ & $0.07 \mathrm{cde}$ & 78.73abc \\
\hline$T 9.1$ & 7.00abcd & $0.33 \mathrm{~g}$ & $16.90 \mathrm{~b}$ & $5.00 \mathrm{~b}$ & $33.33 \mathrm{def}$ & $3.70 \mathrm{f}$ & $0.01 \mathrm{e}$ & $93.89 \mathrm{ab}$ \\
\hline$T 9.2$ & 7.33abcd & $0.00 \mathrm{~g}$ & $0.00 c$ & $0.00 \mathrm{e}$ & $0.00 \mathrm{f}$ & $0.00 \mathrm{f}$ & $0.00 \mathrm{e}$ & $100.00 \mathrm{a}$ \\
\hline$C V$ & 24.3 & 25.65 & 16.95 & 21.10 & 39.20 & 12.22 & 41.41 & 64.60 \\
\hline$L S D$ & 2.9 & 2.7 & 11.77 & 4.68 & 39.10 & 17.36 & 0.14 & 42.78 \\
\hline
\end{tabular}

ears harvested were associated with low damage rates at three weeks after sowing (V3). No damage (0\%) to flowering resulted in the maintenance of a high number of ears harvested per plot. Decrease in number of grain on the ear (cob) was probably the result of floral primordial or a slight pollination of the dichogamy [28]. Both varieties had a high yield in treatments without defoliation. This situation can be explained by the fact that in maize, the grain yield is determined by the quantity of silk and by the length of the period during which the sensitivity is very high [29] [30] [31].

\subsection{Diameter and Length of the Ear (Cob)}

The averages of diameters of the ears were appreciably affected by the factors caused damage, stage of growth and their interaction. These averages varied between $0 \mathrm{~mm}$ and $47.1 \mathrm{~mm}$ respectively for T4.2 and T3.2. Low values of ear diameter were recorded for high damage rates during the flowering stage (VT). Similarly to the ear diameter, the ear length was significantly influenced by the 
same factors. Length values varied between 0 and $17.29 \mathrm{~cm}$ respectively for T9.2 and T5.2. [32] [33] observed that defoliation decreases the size of the ears and it seems that the weight of the grains is more dependent on the genetic factor than on the environmental factor. Following [33], ear length and weight had a positive and significant correlation with all treatment. However, [34] observed that defoliation had non-significant effect on ear length.

Based on results, length ear decreased by $12 \%$ to $100 \%$ in VT treatments, where as other treatments do not have significant effect on ear length (Table 4). These results are in agreement with the finding of [35]. It is indicated that ear length is most affect by some factor such as defoliation time, intensity of defoliation and position of leaves on the plant [36] [37].

\subsection{Marketable Ear Rate}

Marketable ear rates varied between $0 \%$ and $90.47 \%$ respectively for T9.2 and T3.1, T3.2. Most of the healthy ears were harvested under V3. Figure 4 shows the appearance quotations of the ears rated from 1 to 5 compared to the treatment corresponding to flowering stage. The ears of the plants that did not loosed leaves $(0 \%)$ had a quote $=1$, which is marketable. Plants treated with $25 \%$ damage produced ears with a quote score of 1.5 to 2 . Plants treated with $50 \%$ damage showed ears quoted 2.5 to 3.5 . As for the plants treated at $75 \%$ of damage, the quotation was 3.5 to 4 , while the full defoliated plants (100\%), ears had a quotation greater than 4.5 , reducing significantly the rate of ear marketable.

\subsection{Harvest Rate}

Regarding Table 4, is appears that the best harvest rates were recorded after treatments before flowering stage or at V3. The damage caused at stage V3 had no negative effects $(\mathrm{p}>0.05)$ on the production of grain. Low harvest rates $(0.00 \%$ and $3.70 \%)$ were recorded respectively in treatments T9.2 and T9. [35] also reported damage to the silk of maize at $50 \%$ until 10 days later, which reduced yield by reducing the number of ears after 20 days or more, the yield was reduced by reducing the weight of a thousand grains. Various reports also indicated that a partial defoliation of about $25 \%$ to $33 \%$ did not change the weight of the seeds at any stage of seed development.
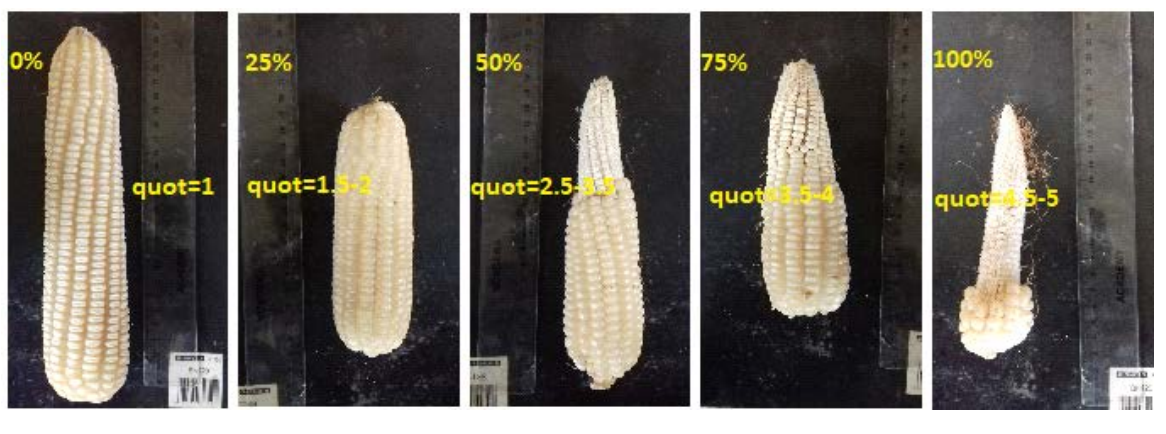

Figure 4. Damage rate $(0 \%, 25 \%, 50 \%, 75 \%, 100 \%)$ and ear quotation (quot $=1$ to 5 ). 


\subsection{Grain Yield}

Estimated per $\mathrm{m}^{2}$, this yield varied between $0.00 \mathrm{~kg} / \mathrm{m}^{2}$ and $0.35 \mathrm{~kg} / \mathrm{m}^{2}$ respectively for T9.2 and T5.2 (Table 4). The best productivity was recorded at the control treatment corresponding to $0 \%$ damage at V3 and VT. Productivity per $\mathrm{m}^{2}$ was significantly affected $(\mathrm{p}<0.05)$ by damage rate and growth stage. Varieties used did not influenced the yield after two periods of simulated attack.

Several biotics and abiotics stresses affect the yield of maize through defoliation. [38] reported that the critical rate of defoliation in maize was $50 \%$; this rate did not affect grain yield and its components.

In accordance with the study made by [39] on sunflowers (Helianthus annuus L.), the yield has been greatly reduced by defoliation at the pre-flowering stage. This is similar to complete defoliation was more detrimental and caused yield loss of $6.4 \%$ to $82 \%$ compared to partial defoliation with loss of yield of $1.5 \%$ to $32.7 \%$. These losses varied with the time of application of the treatment.

Still according to [35], the yield component most affected by leaf loss, for the entire treatment period, was the grain weight decrease from $12.7 \%$ to $53 \%$. However, the number of grains was considerably reduced by $62.3 \%$ when all the leaves were removed 10 days after the appearance of the silk. Thus, the partial leaf removal affected the number of grains much less, approximate decline, $20 \%$. According to [33], the maize plant in complete defoliation had the lowest grain yield, ear weight, number of rows per ear, ear weight and 100 grain weight, but had a percentage, higher grain germination rate and high vigor.

According to [40], the reduction in grain yield was associated with the number of defoliated leaves and this reduction was linked to the decrease in grain number. Based on the results of the trial, early defoliation in the reproductive phase causes yield losses by reducing the number of grains [41].

\subsection{Grain Yield Losses}

The average of grain yield losses (loss) varied between $0 \%$ and $100 \%$ regardless to varieties. These values corresponded respectively for $0 \%$ of damage and $100 \%$ of damage occurring at two growth stages. The losses observed were associated with the high damage rates and they are more accentuated with the damage caused during the flowering stage (VT).

According to [42], percentage yield loss is depending on factors such as on the amount of removed leaves, leaf position on plant and also defoliation time. This hypothesis can be explain by [43], who suggested that the near leaves to ear are main factor of increasing dry matters and growth rate during the development.

This study showed that a significant loss of leaves at the beginning of silk and up to at least 10 days after $50 \%$ of silk had resulted in a reduction in grain yield due to the reduction in the number of grains and regardless of the severity, defoliation in the days after the appearance of the silk considerably reduced the accumulated dry matter [35]. However, the yield declines associated with less severe leaf loss or leaf loss at least 20 days after $50 \%$ silk were largely related to a 
decrease in grain weight. In addition to providing a better understanding of the patterns of dry matter accumulation, these data can be useful for individuals who are required to estimate grain yield after significant loss, due to natural causes, of the leaf area of the plant [35].

\section{Conclusion}

Results of this study showed that cutting of leaves decreases yield because of diminishing of number of grains. In addition, some variables including ear (cob) sizes, percentage of harvest and rate of ear harvested, are decreased at upper than $25 \%$ of defoliation. According to stage of growth imposed on plant, (V3) or (VT), the most change caused by defoliation seen on traits related to yield such as rate of ear harvested, rate of ear marketable and this cause to decrease in yield. This indicates the early reproductive phase specially flowering and pollination is more sensible to any harmful factor to leaves. Concerning the simulation of FAW attacks, the defoliation around $75 \%$ or total defoliation at $100 \%$ at stage V3 and VT would be the critical threshold, because they induce negative effects on the yield causing losses of more than $50 \%$. Full defoliation severely reduced the grain yield and affected its marketability. However, simulations of less than 50\% of damage, occurring at growth stage V3, caused losses of less than $10 \%$. Varieties Mudishi-1 and Mudishi-3 would be able to compensate for losses due to damage up to $25 \%$, occurring at stage V3.

\section{Acknowledgements}

The author would like to acknowledge the staff of the National Institute for Agricultural Study and Research (INERA-Mvuazi) for their assistance during the execution of the research.

\section{Conflicts of Interest}

The authors declare no conflicts of interest regarding the publication of this paper.

\section{References}

[1] Sparks, A.N. (1979) A Review of the Biology of the Fall Armyworm. The Florida Entomologist, 62, 82-87. https://doi.org/10.2307/3494083

[2] Pashley, D.P. (1988) Current Status of Fall Armyworm Host Strains. The Florida Entomologist, 71, 227-234. https://doi.org/10.2307/3495425

[3] Buntin, G.D. (1986) A Review of Plant Response to Fall Armyworm, Spodoptera frugiperda (J. E. Smith), Injury in Selected Field and Forage Crops. The Florida Entomologist, 69, 549. https://doi.org/10.2307/3495389

[4] Wyckhuys, K.A.G. and O’Neil, R.J. (2006) Population Dynamics of Spodoptera frugiperda Smith (Lepidoptera: Noctuidae) and Associated Arthropod Natural Enemies in Honduran Subsistence Maize. Crop Protection, 25, 1180-1190. https://doi.org/10.1016/j.cropro.2006.03.003

[5] FAO and CABI (2019) Community-Based Fall Armyworm (Spodoptera frugiperda) 
Monitoring, Early Warning and Management, Training of Trainers Manual. 1st Edition, Food and Agriculture Organization of the United Nations, Rome.

[6] FAO (2017) Note d'information du Groupe Inter Bailleurs pour l'Agriculture et le Développement Rural en République démocratique du Congo sur la che[10]Nille légionnaire d'automne.

http://cd.one.un.org/content/unct/rdc/fr/home/actualites/attaque-de-che[10]Nilleslegionnaires-sur-les-cultures-de-mais.html

[7] Hruska, A.J. and Gladstone, S.M. (1988) Effect of Period and Level of Infestation of the Fall Armyworm, Spodoptera frugiperda, on Irrigated Maize Yield. The Florida Entomologist, 71, 249. https://doi.org/10.2307/3495428

[8] Aguire, L.A., Hernández-Juàrez, A., Flores, M., Cerna, E., Landeros, J., Frías, G.A. and Harris, M. K. (2016) Evaluation of Foliar Damage by Spodoptera frugiperda (Lepidoptera: Noctuidae) to Genetically Modified Corn (Poales: Poaceae) in Mexico. Florida Entomologist, 99, 276-280. https://doi.org/10.1653/024.099.0218

[9] Cruz, I., Figueiredo, M.L.C., Oliveira, A.C. and Vasconcelos, C.A. (1999) Damage of Spodoptera frugiperda (Smith) in Different Maize Genotypes Cultivated in Soil under Three Levels of Aluminium Saturation. International Journal of Pest Management, 45, 293-296. https://doi.org/10.1080/096708799227707

[10] Ni, X., Xu, W., Blanco, M.H. and Williams, W.P. (2014) Evaluation of Fall Armyworm Resistance in Maize Germplasm Lines Using Visual Leaf Injury Rating and Predator Survey. Insect Science, 21, 541-555. https://doi.org/10.1111/1744-7917.12093

[11] Baubron, F., Zaman-Allah, M.A., Chaipa, I., Chari, N. and Chinwada, P. (2019) Understanding the Factors Influencing Fall Armyworm (Spodoptera frugiperda J.E. Smith) Damage in African Smallholder Maize Fields and Quantifying Its Impact on Yield. A Case Study in Eastern Zimbabwe. Crop Protection, 120, 141-150. https://doi.org/10.1016/j.cropro.2019.01.028

[12] Midega, C.A.O., Pittchar, J.O., Pickett, J.A., Hailu, G.W. and Khan, Z.R. (2018) A Climate-Adapted Push-Pull System Effectively Controls Fall Armyworm, Spodoptera frugiperda (J E Smith), in Maize in East Africa. Crop Protection, 105, 10-15. https://doi.org/10.1016/j.cropro.2017.11.003

[13] CABI (2019) Fall Armyworm (FAW) in "Invasive Species Compendium". https://www.cabi.org/isc/fallarmyworm

[14] Goergen, G., Kumar, P.L., Sankung, S.B., Togola, A. and Tamò, M. (2016) First Report of Outbreaks of the Fall Armyworm Spodoptera frugiperda (J E Smith) (Lepidoptera, Noctuidae), A New Alien Invasive Pest in West and Central Africa. PLoS ONE, 11, e0165632. https://doi.org/10.1371/journal.pone.0165632

[15] Nagoshi, R.N., Meagher, R.L. and Hay-Roe, M. (2012) Inferring the Annual Migration Patterns of Fall Armyworm (Lepidoptera: Noctuidae) in the United States from Mitochondrial Haplotypes. Ecology and Evolution, 2, 1458-1467.

https://doi.org/10.1002/ece3.268

[16] Abrahams, P., Bateman, M., Beale, T., Clottey, V., Cock, M., Colmenarez, Y., Corniani, N., Day, R., Early, R., Godwin, J., Gomez, J., Moreno, G.P., Murphy, S.T., Oppong-Mensah, B., Phiri, N., Pratt, C., Richards, G., Silvestri, S. and Witt, A. (2017) Fall Armyworm: Impacts and Implications for Africa. Outlooks on Pest Management, 28, 196-201.

[17] Day, R., Abrahams, P., Bateman, M., Beale, T., Clottey, V., Cock, M., Colmenarez, Y., Natalia, C., Early, R., Godwin, J., Gomez, J., Moreno, P.G., Murphy, S.T., Oppong-Mensah, B., Phiri, N., Pratt, C., Richards, G., Silvestri, S. and Witt, A. (2017) 
Fall Armyworm: Impacts and Implications for Africa. Outlooks on Pest Management, 28, 196-201. https://doi.org/10.1564/v28 oct 02

[18] Kumela, T., Simiyu, J., Sisay, B., Likhayo, P., Mendesil, E., Gohole, L. and Tefera, T. (2019) Farmers' Knowledge, Perceptions, and Management Practices of the New Invasive Pest, Fall Armyworm (Spodoptera frugiperda) in Ethiopia and Kenya. International Journal of Pest Management, 65, 1-9. https://doi.org/10.1080/09670874.2017.1423129

[19] FAO (2018) Gestion intégrée de la chenille légionnaire d'automne sur le maïs. Un guide pour les champs-écoles des producteurs en Afrique. Organisation des Nations Unies pour l'alimentation et l'agriculture, Rome, 136.

[20] Prasanna, B.M., Huesing, J.E., Eddy, R. and Peschke, V.M. (2018) Fall Armyworm in Africa: A Guide for Integrated Pest Management. 2018. Vii, 109 pages: il. México. CIMMYT. USAID.

[21] Tshaibukole, J.P.K. (2018) Evaluation de la sensibilité aux stress hydriques du maïs (Zea mays L.) cultivé dans la savane du Sud-Ouest de la RD Congo, cas de Mvuazi. Université Pédagogique Nationale, Democratic Republic of the Congo.

[22] Köppen, W. (1936) Das Geographische System der Klimate. In: Köppen W. and Geiger, H., Eds., Handbuch der Klimatologie, Gebr, Borntraeger, Berlin, 1-44.

[23] Fakorede, M.A.B., Badu-Apraku, B., Kamara, A.Y., Menkir, A., and Ajala, S.O. (2003) Maize Revolution in West and Central Africa. An Overview Proceedings of a Regional Maize Workshop, IITA-Cotonou, Republic of Benin, date, 14-1.

[24] FAO (1997)

[25] Kabongo, T., Pongi, K., Mumba, J., Mbuya, K., Kizungu, V. and Kabwe, K. (2016) A Evaluation of Maize Sensitivity in Southwestern Savannah Area of DR Congo. African Journal of Agricultural Science and Technology, 4, 812-817.

[26] Mbuya, K., Nkongolo, K.K., Narendrula, R., Kalonji-Mbuyi, A. and Kizungu, R.V. (2010) Participatory Selection and Characterization of Quality Protein Maize (QPM) Varieties in Savanna Agroecological Region of DR-Congo. Journal of Plant Breeding and Crop Science, 2, 325-332.

[27] Dhopte, A.M. (1984) Effect of Simulated Damage Done to Maize Plants by Voedeer (Caprolus). Field Crops Research, 37, 111-114.

[28] Jones, R.J. and Simmons, S.R. (1983) Effect of Altered Source-Sink Ratio on Growth of Maize Kernels. Crop Science, 23, 129-134. https://doi.org/10.2135/cropsci1983.0011183X002300010038x

[29] Minami, M. (1991) Analytical Studies on High Yielding Ability of Hybrid Maize (Zea mays L.) from the Standing Point of Development Morphology. Journal of the Faculty of Agriculture Shinshu University, 24, 155-164.

[30] Mouhamed, S.G.A. and Ouda, S.A.H. (2006) Predicting the Role of Some Weather Parameters on Maize Productivity under Different Defoliation Treatments. Journal of Applied Sciences Research, 2, 920-925.

[31] Maposse, I.C. and Nhampalele, V.V. (2009) Performance of Cowpea Varieties under Different Defoliation Regimes for Multiple Uses. 9th African Crop Science, Conference Proceedings, Cape Town, South Africa, 28 September-2 October 2009, 279-281.

[32] Heidari, H. (2015) Effect of Defoliation Based on Leaf Position on Maize Yield, Yield Components and Produced Seed Germination. Bulg. Bulgarian Journal of Agricultural Science, 21, 801-805.

[33] Heidari, H., Bahraminejad, S., Maleki, G. and Papzan, A.H. (2009) Response of 
Cumin (Cuminum cyminum L.) to Sowing Date and Plant Density. Research Journal of Agriculture and Biological Sciences, 5, 597-602.

[34] Fasae, O.A., Adu, F.I., Aina, A.B.J. and Elemo, K.A. (2009) Effects of Defoliation Time of Maize on Leaf Yield, Quality and Storage of Maize Leafs as Dry Season Forage for Ruminant Production. Revista Brasileira de Ciências Agrárias, 4, 353-357.

[35] Egharevba, P.N., Horrocks, R.D. and Zuber, M.S. (1976) Dry Matter Accumulation in Maize in Response to Defoliation1. Agronomy Journal, 68, 40-43. https://doi.org/10.2134/agronj1976.00021962006800010011x

[36] Thomison, P.R. and Nafziger, E.D. (2003) Defoliation Affects Grain Yield, Protein, and Oil of TopCross High-Oil Corn. Crop Management, 2, 1-9.

https://doi.org/10.1094/CM-2003-1027-01-RS

[37] Tilahum, A. (1993) Quantitative and Physiological Traits in Maize (Zea mays). Associated with Different Levels of Moisture, Plant Density and Leaf Defoliation in Ethiopia. IARP, 74-80.

[38] Zewdu, T. and Asregid, D. (2001) Effect of Growing Annual Forage Legumes with Maize and Maize Leaf Defoliation on Grain and Stover Yield Components and Undersown Forage Production. Seven Eastern and Southern Africa Regional Maize Conference, Southern Africa, August 2001, 487-490.

[39] Erbas, S. and Baydar, H. (2007) Defoliation Effects on Sunflower (Helianthus annuus L.) Seed Yield and Oil Quality. Turkish Journal of Biology, 31, 115-118.

[40] Allison, J.C.S. and Watson, D.J. (1966) The Production Distribution of Dry Matter in Maize after Flowering. Annals of Botany, 30, 365-381. https://doi.org/10.1093/oxfordjournals.aob.a084082

[41] Siahkouhian, S., Shakiba, M.R., Salmasi, S.Z., Golezani, K.G. and Toorchi, M. (2012) Defoliation Effects on Yield Components and Grain Quality of Three Corn Cultivars. International Conference on Environment, Agriculture and Food Sciences, Phuket, 11-12 August 2012.

[42] Shapiro, C.A., Peterson, T.A. and Flowerday, A.D. (1986) Yield Loss due to Simulated Hail Damage on Corn: A Comparison of Predicted and Actual Values. Agronomy Journal, 78, 585-589.

https://doi.org/10.2134/agronj1986.00021962007800040006x

[43] Barimavandi, A.R., Sedaghathoor, S. and Ansari, R. (2010) Effect of Different Defoliation Treatments on Yield and Yield Components in Maize (Zea mays L.) Cultivar of S.C704. Australian Journal of Crop Science, 4, 9-15. 